Subbaiyan, B., P. Samydurai, M. Karthik Prabu, R. Ramakrishnan and V. Thangapandian 2014. Inventory of rare, endangered and threatened (RET) plant species in Maruthamalai Hills, Western Ghats of Tamilnadu, South India. Our Nature. 12(1): 37-43. DOI: http://dx.doi.org/10.3126/on.v12i1.12255

\title{
Inventory of Rare, Endangered and Threatened (RET) Plant Species in Maruthamalai Hills, Western Ghats of Tamilnadu, South India
}

\author{
B. Subbaiyan", P. Samydurai, M. Karthik Prabu, R. Ramakrishnan and V. \\ Thangapandian \\ P.G. and Research Department of Botany, Kongunadu Arts and Science College (Autonomous), Coimbatore - \\ 641 029, TamilNadu, India \\ *E-mail: bsubbaiyan@gmail.com
}

Received: 02.02.2014, Accepted: 09.09.2014

\begin{abstract}
The present study deal with identification of rare, endanger and threatened plants in Maruthamalai Hills, part of Southern Western Ghats of Coimbatore District, Tamilnadu. In this investigation 30 rare, endangered and threatened (RET) plant species belongs to 15 families were identified and documented. Names of plants and RET category was gathered from IUCN annual reports and standard research articles. Enumerated plants were categorized in rare, endangered, endemic and threatened, species such as Caralluma bicolor, Terminalia arjuna, Ceropegia juncea, Rubia cordifolia, Celastrus paniculatus, Gloriosa suberpa, Gymnema sylvestres and so on. Finally it has been suggested that the RET medicinal plants are need to be proper conservation and management plans before it lost forever.
\end{abstract}

Key words: Medicinal plants, Caralluma bicolor, endangered, conservation.

\section{Introduction}

In India, there are over 17,500 species of higher plants, 64 gymnosperms, 1,200 pteridophytes, 2,850 bryophytes, 2,021 lichens, 15,500 fungi and 6,500 algae were reported. India is rich in its own flora that is, endemic plant species $(5,725$ angiosperms, 10 gymnosperms, 193 pteridophytes, 678 bryophytes, 260 liverworts, 466 lichens, 3,500 fungi and 1,924 algae) (Sanjappa, 2005). The important advantages claimed for therapeutic uses of medicinal plants in various ailments are their safety besides being economical, effective and their easy availability (Atal and Kapoor, 1989; Siddiqui, 1993). Now a day's numerous medicinal plants are used to cure several diseases in developing countries. The aromatic medicinal plants are containing large amount of secondary metabolites and essential oils of traditional and therapeutic importance. So many desirable drugs are isolated from various types of plant parts like root, leaf and stem. Several local people still depended on the medicinal plants for their primary healthcare and treatment of various diseases (Samydurai et al., 2012).

The Ministry of Environment and Forest (MoEF) of Indian Government has identified and documented approximately 9500 plant species, which plays an important role in the pharmaceutical industry. As estimated by the Exim Bank, 
the international market of medicinal plants related trade showed that the use of these plants had a growth rate of $7 \%$ per annum and the annual cost of usage of these plants is valued as 1200 million (Jose et al.,2001). According to Sarasan et al. (2006), more than eight thousand plant species were added to the International Union for the Conservation of Nature Resources (ICUN) and a RET list of Threatened Species during the period 1996-2004. During the same period, these authors noted that the number of plants recorded as "critically endangered" are increased by over $60 \%$. The International Union for the Conservation of Nature (ICUN) and the World Wildlife Fund (WWF) estimated that up to 60,000 higher plant species could become extinct or nearly extinct by the year 2050, if the current trends of utilization continue (Etkin, 1998; Phani Kumar et al., 2011).

A rare species are one with small population that is not presently endangered but is at risk, an endangered species is one, which is in danger of extinction throughout all or of a significant portion of its range and a threatened species is one, which is likely to become endangered in the foreseeable future (IUCN, 1978; Bryde, 1979; Nayar and Sastry, 1990). The current trend toward increased commercialization has resulted in overharvesting of some medicinal plants, many of which have become threatened. Threatened medicinal plant species have become the focus of world attention because they represent vanishing flora in need protection and conservation and because of their role as an essential commodity for health care (Gustafsson et al., 2002; Kala, 2002).The present investigation was carried out to explore the distribution of rare, endemic, endangered and threatened (RET) category plant species in Marudhamalai hills, Western Ghats of Tamil Nadu, India. These kinds of plants are in need of proper conservation and management plans for its medicinal properties and medicinal plant resources before it lost forever.

\section{Materials and methods \\ Study area}

Maruthamalai hills, part of Western Ghats in Coimbatore district of Tamil Nadu lies between $76^{\circ} 45^{\prime}$ and $76^{\circ} 55^{\prime} \mathrm{E}$ and $11^{\circ} 0^{\prime}$ and $11^{\circ} 5^{\prime} \mathrm{N}$ (Fig. 1). The forest type of this

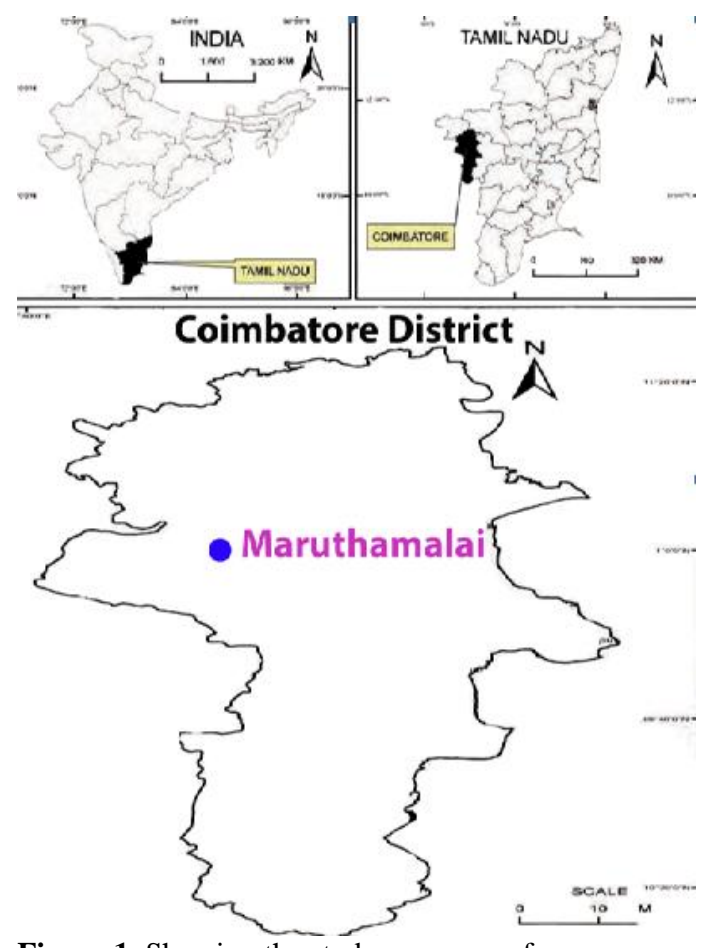

Figure 1. Showing the study area map of Maruthamalai Hills, Coimbatore district, Western Ghats of Tamilnadu, India.

region is dry deciduous (Champion and Seth, 1968). Annual rainfall is around $450 \mathrm{~mm}$ and temperature in a year is varying 
between $17^{\circ} \mathrm{C}$ and $38^{\circ} \mathrm{C}$. The hills occupy the altitudinal range between 450 and 975 msl. The soil is generally shallow with sandy loam texture and rocky substratum is available at steeply area (Paulsamy, 2011).

The survey was carried out during the month of January 2012 to April 2013 on visited various seasons and observed distribution of plant species. On the basis of RET plants identification and collection from different area of Maruthamalai hills as well as carefully documented. The plants are enumerated alphabetically with their botanical name with author citation, family name; habit/life form by referring to standard flora (Gamble and Fischer, 191536; Matthew, 1983; Nair and Henry, 1983; Chandrabose and Nair, 1988) and threat status referred by CAMP, IUCN plants list and discussed specific research situation. Plants were identified and confirmed with the authentic herbarium of Botanical Survey of India (Southern Circle), Coimbatore. Plants were initially identified by their vernacular name through consultation with the local people. The voucher specimens were deposited in the Department of Botany, Kongunadu Arts and Science College (Autonomous), Coimbatore, Tamilnadu, India.

\section{Results and discussion}

The results of the study have revealed that 30 plant species belonging to 16 families 28 genera (Tab. 1). Among them 11 were herbs, 7 were trees, 8 were climbers and 4 shrubs. In the present study the maximum number of rare, endangered and threatened medicinal plant species belongs to the family Asclepiadaceae they cover 9 species, followed by Acanthaceae and Fabaceae families are each 3 species are in RET list category. In Rubiaceae and Liliaceae families, each two species were documented and other families like Alangiaceae, Commelinaceae, Meliaceae, Euphourbiaceae, Mimosaceae, Burseraceae, Sterculiaceae, Cycadaceae, Combretaceae, Celastraceae and Santalaceae, each one species were listed. Among the 30 species divided into various categories of RET plant listed out, 15 were rare $(R), 6$ were endemic $(E), 2$ were Vulnerable (VU), 1 was lost near critical endangered (C. EN), 4 were endangered (EN), 1 was lost near threatened (NT), 1 was threatened $(\mathrm{T})$ were observed in our study area of Maruthamalai hills (Fig. 2).

Gritto et al. (2012) reported that the RET plant species surveyed in Pachamalai hills had identified 15 plant species are RET categories such as, Santalum album, Decalepis hamiltonii, Terminalia arjuna and Gloriosa superba were mentioned threatened (T), near threatened (NT) and endangered (EN). Pattanaik et al. (2009) also reported RET species like Celastrus paniculatus, Cycas beddomei, Decalepis hamiltonii, Gloriosa superba and Santalum album were declared as RET listed by IUCN in the Eastern Ghats of Orissa. Marudhamalai hills have rich biodiversity and it has large amount of medicinal plants which are used to cure the various diseases. Suitable microclimatic condition may be attributed for rich diversity of taxa in the study area throughout the hill range from foothills to top (Paulsamy, 2011). Recently, many researchers were documented in Maruthamalai hills had nearly 15 species rare and endemic medicinal plant species used by the tribal peoples and traditional healers (Jayanthi et al., 2011; Paulsamy, 2011; Sarvalingam et al., 2012; Sindhuja et al., 2012). 
B. Subbaiyan, P. Samydurai, M. Karthik Prabu, R. Ramakrishnan and V. Thangapandian / Our Nature (2014), 12(1): 37-43.

Table 1. List of plant species

\begin{tabular}{|c|c|c|c|c|c|c|}
\hline $\mathbf{S N}$ & Binomial name & Family & $\begin{array}{l}\text { Habitat } \\
\text { /life } \\
\text { form }\end{array}$ & $\begin{array}{l}\text { Ecological } \\
\text { status }\end{array}$ & $\begin{array}{l}\text { Flower/ } \\
\text { Fruiting }\end{array}$ & Source \\
\hline 1 & Adenanthera pavonina $\mathrm{L}$. & Mimosaceae & Tree & $\mathrm{R}$ & Mar-Aug & $\begin{array}{l}\text { Sarvalingam et al. } \\
\text { (2012) }\end{array}$ \\
\hline 2 & $\begin{array}{l}\text { Alangium salvifolium (L.F.) } \\
\text { Wang. }\end{array}$ & Alangiaceae & Tree & $\mathrm{R}$ & Mar- Jun & Jayanthi et al. (2011) \\
\hline 3 & Andrographis echinoids Nees & Acanthaceae & Herb & $\mathrm{R}$ & Oct-Dec & Jayanthi et al. (2011) \\
\hline 4 & Asparagus fysonii J.F. Macbr & Liliaceae & Shrub & $\mathrm{R}$ & Nov-Apr & $\begin{array}{l}\text { Prabhukumar et al. } \\
\text { (2013) }\end{array}$ \\
\hline 5 & Barleria buxifolia $L$. & Acanthaceae & Herb & $\bar{E}$ & Nov-Mar & $\begin{array}{l}\text { Sindhuja et al. } \\
\text { (2012),Prabhukumar } \\
\text { et al. (2012) }\end{array}$ \\
\hline 6 & Barleria acuminate Wight. & Acanthaceae & Herb & $\mathrm{E}$ & Nov-Mar & $\begin{array}{l}\text { Sindhuja et al. } \\
\text { (2012), } \\
\text { Prabhukumar et al. } \\
\text { (2013) }\end{array}$ \\
\hline 7 & $\begin{array}{l}\text { Caralluma bicolor VS. } \\
\text { Ramach.et al }\end{array}$ & Asclepiadaceae & Herb & $\bar{E}$ & Sep-May & $\begin{array}{l}\text { Prabhukumar et al. } \\
\text { (2013) }\end{array}$ \\
\hline 8 & $\begin{array}{l}\text { Caralluma indica (Wight } \\
\text { \&Arn.) N.E.Br. }\end{array}$ & Asclepiadaceae & Herb & $\mathrm{R}$ & Sep-May & $\begin{array}{l}\text { Prabhukumar et al. } \\
\text { (2013) }\end{array}$ \\
\hline 9 & Ceropegia juncea Roxb. & Asclepiadaceae & Climber & $\mathrm{R}$ & Oct-Mar & Murthy et al. (2012) \\
\hline 10 & $\begin{array}{l}\text { Ceropegia candelabrum var } \\
\text { biflora (L.) Ansari }\end{array}$ & Asclepiadaceae & Climber & $\mathrm{R}$ & Aug-Dec. & Murthy et al. (2012) \\
\hline 11 & Celastrus paniculatus Wild. & Celastraceae & Climber & NT & Nov-Mar & $\begin{array}{l}\text { Pattanaik et al. } \\
\text { (2009) }\end{array}$ \\
\hline 12 & Commiphora wightii (Arn.) & Burseraceae & Shrub & EN & Sep-Jan & IUCN (2010) \\
\hline 13 & $\begin{array}{l}\text { Cynotis tuberosa (Roxb.) } \\
\text { Schult }\end{array}$ & Commelinaceae & Herb & $\mathrm{E}$ & Jun-Aug & $\begin{array}{l}\text { Sindhuja et al. } \\
\text { (2012) }\end{array}$ \\
\hline 14 & Cipadessa buccifera (Roxb) & Meliaceae & Shrub & $\mathrm{R}$ & Nov-Apr & Jayanthi et al. (2011) \\
\hline 15 & Cycas beddomei Dyer. & Cycadaceae & Tree & C.EN & Jul-Dec & $\begin{array}{l}\text { Pattanaik et al. } \\
(2009)\end{array}$ \\
\hline 16 & $\begin{array}{l}\text { Decalepis hamiltonii } \\
\text { Wight.\& Arn. }\end{array}$ & Asclepiadaceae & Climber & $\mathrm{EN}$ & Aug-May & $\begin{array}{l}\text { Pattanaik et al. } \\
\text { (2009), } \\
\text { Nandhagopalan et } \\
\text { al. (2012) }\end{array}$ \\
\hline 17 & Gloriosa superba L. & Liliaceae & Climber & EN/NT & July-Oct & $\begin{array}{l}\text { Pattanaik et al. } \\
\text { (2009), } \\
\text { Nandhagopalan et } \\
\text { al. (2012) }\end{array}$ \\
\hline 18 & $\begin{array}{l}\text { Gymnema sylvestre (Retz.) } \\
\text { R.Br. ex Schult. }\end{array}$ & Asclepiadaceae & Climber & VU & Apr-May & $\begin{array}{l}\text { Pattanaik et al. } \\
\text { (2009) }\end{array}$ \\
\hline 19 & Helicteres isora $\mathrm{L}$. & Sterculiaceae & Tree & $\mathrm{R}$ & Dec-Mar & $\begin{array}{l}\text { Sarvalingam et al. } \\
(2012)\end{array}$ \\
\hline
\end{tabular}


B. Subbaiyan, P. Samydurai, M. Karthik Prabu, R. Ramakrishnan and V. Thangapandian / Our Nature (2014), 12(1): 37-43.

\begin{tabular}{|c|c|c|c|c|c|c|}
\hline 20 & $\begin{array}{l}\text { Hemidesmus indicus (L.) R. } \\
\mathrm{Br}\end{array}$ & Asclepiadaceae & Herb & $\mathrm{R}$ & Nov-Feb & $\begin{array}{l}\text { Arul Manikandan } \\
(2005)\end{array}$ \\
\hline 21 & Indigofera uniflora Buch. & Fabaceae & Herb & $\mathrm{E}$ & Jun-Nov & $\begin{array}{l}\text { Sindhuja et al. } \\
\text { (2012) }\end{array}$ \\
\hline 22 & $\begin{array}{l}\text { Mundulea sericea (Willd.) A. } \\
\text { Chev. }\end{array}$ & Fabaceae & Shrub & $\mathrm{R}$ & Nov-Jan & $\begin{array}{l}\text { Sarvalingam et al. } \\
(2012)\end{array}$ \\
\hline 23 & Phyllanthus reticulates Poir & Euphourbiaceae & Herb & $\mathrm{R}$ & Nov-Feb & $\begin{array}{l}\text { Sarvalingam et al. } \\
(2012)\end{array}$ \\
\hline 24 & $\begin{array}{ll}\text { Pterocarpus } & \text { marsupium } \\
& \text { Roxb }\end{array}$ & Fabaceae & Tree & $\mathrm{R}$ & Nov-Apr & $\begin{array}{l}\text { Sarvalingam et al. } \\
\text { (2012) }\end{array}$ \\
\hline 25 & Rubia cordifolia $\mathrm{L}$ & Rubiaceae & Herb & VU & Jun-Aug & $\begin{array}{l}\text { Pattanaik et al. } \\
\text { (2009) }\end{array}$ \\
\hline 26 & Santalum album $\mathrm{L}$. & Santalaceae & Tree & NT/EN & Dec-Apr & $\begin{array}{l}\text { Pattanaik et al. } \\
\text { (2009), } \\
\text { Nandhagopalan et }\end{array}$ \\
\hline 27 & Spermacoca hispida $\mathrm{L}$. & Rubiaceae & Herb & $\mathrm{E}$ & Jul-Oct & $\begin{array}{l}\text { Sindhuja et al. } \\
(2012)\end{array}$ \\
\hline 28 & $\begin{array}{l}\text { Terminalia arjuna (Roxb.) } \\
\text { ex. DC. W\&A. }\end{array}$ & Combretaceae & Tree & $\mathrm{T}$ & $\begin{array}{l}\text { Mar- } \\
\text { June/ } \\
\text { Sep-Nov }\end{array}$ & $\begin{array}{l}\text { Nandhagopalan } e t \\
\text { al. (2012) }\end{array}$ \\
\hline 29 & $\begin{array}{l}\text { Tylophora indica (Burn. f.) } \\
\text { Merr. }\end{array}$ & Asclepiadaceae & Climber & $\mathrm{R}$ & Aug-Mar & $\begin{array}{l}\text { Sarvalingam et al. } \\
\text { (2012) }\end{array}$ \\
\hline 30 & $\begin{array}{l}\text { Wattakaka volubilis (Linn. f.) } \\
\text { Benth ex. Hook f. }\end{array}$ & Asclepiadaceae & Climber & $\mathrm{R}$ & Aug-Mar & $\begin{array}{l}\text { Udhayasankar et al. } \\
(2012)\end{array}$ \\
\hline
\end{tabular}
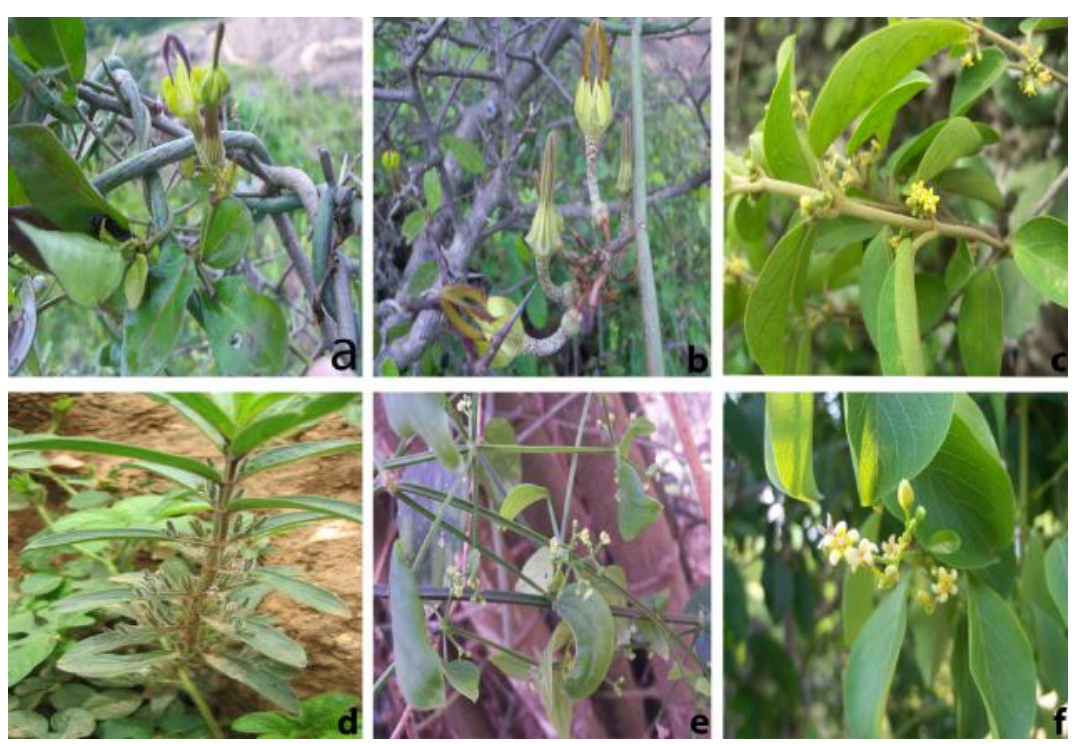

Figure 2. Invention of rare, endanger and threatened (RET) plant species in Maruthamalai Hills, Coimbatore district, Western Ghats of Tamilnadu, South India. a- Ceropegia candelabrum var biflora, b- Ceropegia juncea, cGymnema sylvestre, d- Andrographis echinoids, e-Rubia cardifolia, f-Decalepis hamiltonii. 
Most of the plants which are known to have medicinal proprieties and categorized into RET status. This lack of effort to draw resources may result in their depletion from natural habitats. There is great need to create awareness among the indigenous communities about endangered medicinal plants, if over exploited to meet market demand (Choudhary et al., 2008). Even today, tribes and some community practice herbal medicine to cure a variety of disease and disorders. They collect and preserve locally available wild species, unaware of the fact that some of the species are endemic or some in the RET category. They are not aware about the importance of such species, which need aware to conserve wild populations without lost.

\section{Conclusion}

The findings of the present study documented the RET listed plant species, that species are closely contact with tribal community and also drug industries. Over exploitation of these species may cause the dangerous period of nature. By conducting the awareness program among the tribal's, we can promote the knowledge about importance of diversity and also can conserve the RET plants. We trained to make the herbal garden and proper cultivation of important RET plants like, Decalepis hamiltonii, Gymnema sylvestre, Gloriosa superba and Hemidesmus indicus to give them livelihood.

\section{Acknowledgements}

I take this opportunity to express my profound gratitude and deep regards to my guide (Dr. V. Thangapandian, Associate Professor) for his exemplary guidance, monitoring and constant encouragement throughout the course work. All the authors are greatly thankful to Dr. G.V.S. Moorthy, Scientist $\mathrm{F}$ and Joint Director, Botanical Survey of India, Southern circle, Coimbatore for helping identification of plants and library resources.

\section{References}

Arul Manikandan, P.N. 2005. Folk herbal medicine: A Survey on the paniya tribes of mundakunnu village of the Nilgiri hills, South India. Ancient Science of Life 25(1): 21-27.

Atal, C.K. and B.M. Kapoor 1989. Cultivation and utilization of medicinal plants (Eds. PID CSIR)

Bryde, M.B. 1979. Information needed to use the endangered species Act for plant conservation, Geographical Data Organization, Rare plant conservation, New york.

Champion, H.G. and Seth 1968. A revised survey of the forest types of India. Govt. of India Press, Nasik, India.

Chandrabose, M. and N.C. Nair, N.C. 1988. Flora of Coimbatore. Bishen Singh Mahendra Pal Singh, Dehra Dun.

Choudhary, K., M. Sing and U. Pillai 2008. Ethno botanical Survey of Rajasthan - An Update. American- Eurasian Journal of Botany 1(2): 3845.

Etkin, N.L. 1998. Indigenous patterns of conserving biodiversity: pharmacologic implications. Journal of Ethnopharmacology 63: 233-245. http://dx.doi.org/10.1016/S0378-8741(98)00102-0

Gamble, J.S. and C.E.C. Fischer 1915-1936. Flora of the Presidency Madras. Vol. I-III. Adlard and Co. London (Reprinted 1956). Botanical Survey of India, Calcutta.

Gritto, M.J., A. Aslam. and V. Nandagopalan 2012. Ethnomedicinal survey of Threatened plants in Pachamalaihills, Tiruchirapalli district, Tamilnadu, India. Int. J. Res. Ayur. Pharm. 3(6) 844-846. http://dx.doi.org/10.7897/22774343.03634

Gustafsson, M.H.G., V. Britich and P.F. Stevens 2002. Phylogeny of Clusiaceae based on rbcL sequences. International J. of Plant Science 163: 1045-1054. http://dx.doi.org/10.1086/342521

IUCN 1978. Plant Red Data Book. Royal Botanic Garden, Kew, England. 
B. Subbaiyan, P. Samydurai, M. Karthik Prabu, R. Ramakrishnan and V. Thangapandian / Our Nature (2014), 12(1): 37-43.

IUCN 2010. "IUCN Red List of Threatened species" Version 2010.2 http://www.iucnredlist.org. Cited at 13 July 2010.

Jayanthi, P., A. Rajendran, Binu Thomas, V. Aravindhan and R. Sivalingam 2011. Biodiversity of Lithophytes in Madukkarai Hills of Southern Western Ghats of Coimbatore district, Tamil Nadu, India. International Journal of Biological Technology 2(2):76-82.

Jose, S.C., K. Sivaraman and H.P. Singh 2001. Medicinal and aromatic plants. Floriculture Today. pp 24-32.

Kala, C.P. 2002. Medicinal plants of Indian TransHimalaya. Bishen Singh Mahendra Pal Singh. Dehra-Dun, India.

Matthew, K.M. 1983. The Flora of the TamilNadu Carnatic. The Rapinat Herbarium, St. Joseph's College, Tiruchirapalli, India.

Nair, N.C. and A.N. Henry 1983. Flora of Tamilnadu India. Series-I. Analysis. Vol. I. Botanical Survey of India, Ciombatore.

Nayar, M.P. and A.R.K. Sastry 1990. Red Data Book of Indian plants. Vol I, II and III, Botanical Survey of India, Calcutta, India.

Pattanaik, C., C.S. Reddy and K.N. Reddy 2009. Ethno-medicinal survey of threatened plants in Eastern Ghats, India. Our Nature 7: 122-128.

Paulsamy, S. 2011. Maruthamalai hills of Western Ghats, Coimbatore District, and Tamil Nadu. A potential ecosystem for medicinal plants. Journal of Research in Plant science 1: 12-26.

Phani Kumar, G., R. Kumar, O.P. Chaurasia and S. Bala Singh 2011. Current status and potential prospects of medicinal plant sector in transHimalayan Ladakh. Journal of Medicinal Plants Research 5(14): 2929-2940.

Prabhukumar, K.M., V. Sreeraj, B. Thomas, K.M. Manudev and A. Rajendran 2012. Validation and documentation endemic and threatened (RET) plants from Nilgiri, Kanuvai and Madukkarai forest of Southern Western Ghats, India. Journal of Threatened Taxa 4(15): 3436-3442. http://dx.doi.org/10.11609/JoTT.o3145.3436-42

Samydurai, P., S. Jatheshkumar, V. Aravinthan and V. Thangapandian 2012. Survey of wild aromatic ethnomedicinal plants of Velliangiri hills in the Southern Western Ghats of Tamilnadu, India. International journal of Medicinal Aromatic plants 2: 229-234.

Sanjappa, M. 2005. Plant diversity in India-status, conservation and challenges (P. Maheshwari Medal Award Lecture). In XXVIII Conference of Indian Bot. Soc., Oct. 24(26): 5-6.

Sarasan, V., R. Cripps, M.M. Ramsay, C. Atherton, M. Mcmichen, G. Prendergast and J.K. Rowntree 2006. Conservation in vitro of threatened plantsprogress in the past decade. In Vitro Cellular and Developmental Biology - Plant 42: 206-214. http://dx.doi.org/10.1079/IVP2006769

Sarvalingam, A., A. Rajendran and R. Sivalingam 2012. Documentary of woody flora and its usage in Maruthamalai Hills of the Southern Western Ghats of Coimbatore district, India. Research in Plant Biology 2(1): 7-14.

Siddiqui, H.H. 1993. Safety of herbal drugs-an overview. Drugs News and Views 1(2): 7-10.

Sindhuja, R., A. Rajendran and P. Jayanthi 2012. Herbaceous life forms of Maruthamalai Hills, Southern Western Ghats, India. International Journal of Medicinal and Aromatics Plants 2(4): 625-631.

Udhayasankar, M.R., U. Danya and K. Arumugasamy 2012. Phytochemistry and free radical scavenging activity of Wattakaka volubilis (Linn. f.) Benth ex. Hook f. (Asclepiadaceae) -A rare and threatened medicinal plant. International Journal of Pharm. Tech. Research 4(3): 1025-1032. 